\title{
Pengaruh Keterampilan Proses IPA Kelas IV dengan Model Student Facilitator and Explaining (SFE)
}

\author{
Nikita Nabila'* ${ }^{1 *}$ Ahmad Harjono ${ }^{2}$, Ida Ermiana ${ }^{1}$ \\ Program Studi Pendidikan Guru Sekolah Dasar, Universitas Mataram, Mataram, Indonesia \\ ${ }^{2}$ Program Studi Pendidikan Fisika, Universitas Mataram, Mataram, Indonesia \\ "Corresponding author: nabilanikita28@gmail.com
}

\begin{abstract}
Abstrak: Tujuan penelitian ini untuk mengetahui. pengaruh model student facilitator and explaining (sfe) terhadap keterampilan proses IPA. Jenis penelitian ini menggunakan Quasi Eksperimental Design tipe Nonequivalent Control Group Design. Populasi dalam penelitian ini menggunakan siswa kelas IV SDN Gugus 6 Narmada yang berjumlah 5 Sekolah sedangkan sampel yang digunakan dalam penelitian ini yaitu siswa kelas IV di SDN 2 Golong dan SDN 3 Presak yang diambil menggunakan purposive sampling. Instrumen pengumpulan data yang digunakan adalah lembar observasi keterlaksanaan pembelajaran untuk melihat keterlaksanaan pembelajaran menggunakan model student facilitator and explaining dan tes unjuk kerja untuk melihat keterampilan proses IPA. Teknik analisis data yang digunakan yaitu independent sample t-test dengan 2 uji prasyarat yakni uji normalitas menggunakan rumus kolmogrov-smirnov dan uji homogenitas menggunakan rumus levene test statistik berbantuan SPSS 21.0 for windows. Uji hipotesis menggunakan rumus independent sample $t$-test diperoleh $t_{\text {hitung }}$ sebesar 3,558 dan $t_{\text {tabel }}$ sebesar 1,664 dengan taraf signifikan 0.05 menunjukkan bahwa $\mathrm{H}_{\mathrm{a}}$ diterima $\mathrm{H}_{0}$ ditolak. Dengan demikian dapat disimpulkan bahwa ada pengaruh model student facilitator and explaining (SFE) terhadap keterampilan proses IPA kelas iv sdn gugus 6 kecamatan Narmada Tahun Ajaran 2020/2021.
\end{abstract}

Kata Kunci: model student facilitator and explaining, keterampilan proses, IPA, Sekolah Dasar

Abstract: The purpose of this research is to find out. the influence of the student facilitator and explaining (SFE) model on science process skills. This type of research uses Quasi Experimental Design type No nequivalent Control Group Design. The population in this study used 5 grade students at SDN Gugus 6 Narmada, while the sample used in this study were fourth grade students at SDN 2 Golong and SDN 3 Presak who were taken using purposive sampling. The data collection instrument used was the learning implementation observation sheet to see the learning activity using the student facilitator and explaining model and the performance test to see the science process skills. The data analysis technique used is the independent sample t-test with 2 prerequisite tests, namely the normality test using the KolmogrovSmirnov formula and the homogeneity test using the Levene test statistical formula assisted by SPSS 21.0 for windows. Hypothesis testing using the independent sample $t$-test formula obtained $t$ count of 3.558 and $t$ table of 1.664 with a significant level of 0.05 indicating that Ha is accepted HO is rejected. Thus, it can be concluded that there is an influence of the student facilitator and explaining (SFE) model on the science process skills of class IV to cluster 6 of Narmada sub-districts in the 2020/2021 academic year.

Keywords: student facilitator and explaining model, process skills, science, elementary school

\section{PENDAHULUAN}

Pendidikan adalah usaha dan terencana mewujudkan belajar dan proses pembelajaran agar peserta didik secara aktif mengembangkan potensi dirinya untuk memiliki kekuatan spiritual keagamaan, pengendalian diri, kepribadian, kecerdasan akhlak mulia serta keterampilan proses yang diperlukan dirinya, masyarakat, bangsa dan negara (Undang-Undang Nomor 20 Tahun 
2003 Pasal 1 tentang Sistem Pendidikan Nasional). Menurut Trianto (dalam Mustikasari 2019:2). Ilmu pengetahuan alam (IPA) adalah salah satu mata pelajaran dalam Kurikulum 2013 yang merupakan suatu kumpulan pengetahuan yang tersusun seacara sistematik dan dalam penggunaan secara umum terbatas pada gejala-gejala alam dan berkembangnya tidak hanya ditandai oleh adanya kumpulan fakta, Tetapi adanya metode ilmiah. Dalam pembelajaran menggunakan model SFE dapat mengatur strategi dan tarik yang meliputi menentukan tindakan, dan berinteraksi dengan orang lain. Untuk mengembangkan meningkatkan motivasi dan aktif dalam pembelajaran peserta didik dalam menggunakan model SFE ini sangat berpengaruh dalam proses sehingga dapat mencapai tujuan pembelajaran yang diinginkan dan maksimalkan hasil belajar peserta didik.

Untuk mengubah perilaku manusia maka harus ada peranan penting dari proses belajar yang mengerjakan bagaimana seseorang tersebut mampu berpikir dan mengerjakan sesuatu hal yang dapat berpengaruh kepada perubahan perilaku individu seseorang tersebut (Nai, 2017). Pembelajaran yang optimal terhadap perubahan perilaku peserta didik yang cenderung pasif menjadi aktif maka dapat diterapkan suatu model SFE. Menurut Mawarsari dkk (2014), Model SFE dapat menjadikan peserta didik aktif dalam pembelajaran. Model ini mampu meningkatkan wawasan dan pengembangan kemampuan berpikir anak karena dalam proses belajar terjadi interaksi antar pendidik dengan peserta didik begitupun sesama peserta didik dalam hal bertukar pendapat dan gagasan, secara materi yang disajikan dihubungkan dengan kehidupan sehari-hari terhadap alam sekitar sehingga mendorong motivasi belajar peserta didik dan aktif dalam belajar (Rezki dkk, 2018).

Salah satu model pembelajaran kooperatif adalah model SFE mendemonstrasikan materi di depan peserta didik lalu memberikan mereka kesempatan untuk menjelaskan kepada temantemannya dalam menggunakan model SFE merupakan rangkai penyajian materi ajar yang di awali dengan penjelasan secara terbuka, memberi kesempatan peserta didik untuk menjelaskan kembali kepada peserta didik. Menurut Kurniasih, dkk (2015). Model pembelajaran SFE ini merupakan model pembelajaran yang melatih peserta didik untuk dapat mempresentasikan ide atau gagasan mereka pada teman-temanya. Model pembelajaran ini akan relevan apabila peserta didik secara aktif ikut serta dalam merancang materi pembelajaran.

Menurut Lestari dkk (2017) model pembelajaran SFE berpengaruh terhadap keterampilan proses IPA diantaranya yaitu terdapat kegiatan belajar yang memfokuskan pada proses pembelajaran melalui pengalaman langsung. Artinya peserta didik berperan aktif dalam pembelajaran dan setiap pembelajaran peserta didik akan dibimbing untuk dilatih keterampilan proses IPA.

Setiap pembelajaran IPA, peserta didik dilatih untuk memiliki keterampilan proses IPA melalui berbagai kegiatan dan salah satunya adalah kegiatan bertanya. Mulai kegiatan bertanya peserta didik akan dibimbing untuk pertanyaan terkait objek tertentu, lalu peserta didik dibimbing untuk menemukan jawabannya yang dianggap benar selanjutnya setiap peserta didik hendaknya diberikan kesempatan untuk mengambangkan kemampuan berpikirnya dalam menjelaskan masalah, guru sering kali melupakan pendapat yang dikemukakan oleh peserta didik.

Berdasarkan uraian di atas model pembelajaran SFE ini memberikan aplikasi kepada peserta didik yang sangat mudah untuk dalam pembelajaran, sehingga peserta didik dapat mencapai tujuan pembelajaran dengan cara aktif dan efisien, dengan menerapkan model pembelajaran SFE terbimbing yang mencapai pemahaman konsep peserta didik pada pembelajaran IPA di kelas IV.

Keterampilan proses sains adalah seluruh keterampilan ilmiah yang digunakan untuk menemukan konsep atau teori dalam rangka mengembangkan konsep yang telah ada yang menyangkal penemuan sebelumnya. Walaupun diskusi sudah dilaksanakan tetapi peserta didik belum aktif, sehingga bisa diperlukan untuk meningkatkan motivasi belajar peserta didik, mendorong tumbuh dan perkembangan potensi berpikir kritis peserta didik secara optimal. Oleh sebab itu, peneliti ingin melakukan penelitian untuk mengetahui pengaruh SFE terhadap 
keterampilan proses IPA Peserta didik di SDN Gugus 6 Kecamatan Narmada Tahun Pelajaran $2020 / 2021$.

Menurut Taniredja dalam Wiratningsih dkk. (2014) menyatakan bahwa model pembelajaran Student Facilitator and Explaining (SFE) adalah model pembelajaran dimana peserta didik mempresentasikan idea atau pendapat kepada peserta didik lainya. Sehingga dalam model SFE ini guru memberikan kesempatan kepada peserta didik untuk menyampaikan gagasannya dari materi yang sudah dipahami. Model pembelajaran SFE menjadikan peserta didik sebagai fasilitator dan diajak berpikir dengan begitu akan menghasilkan pertukaran informasi yang lebih mendalam dan lebih menarik serta meningkatkan rasa percaya diri pada peserta didik.

Menurut Huda (Nuryanto, 2018:50) SFE dapat melatih peserta didik menjadi guru, peserta didik diberikan kesempatan untuk mengulangi guru yang telah didengar, selain itu juga dapat memacu motivasi peserta didik menjadi yang terbaik dalam menjelaskan materi ajar, selain itu penerapan strategi SFE ini dapat digunakan untuk mengetahui kemampuan peserta didik menyampaikan ide atau gagasan.

Demikian dapat di simpulkan bahwa model SFE merupakan model pembelajaran yang memberikan kesempatan kepada peserta didik untuk mengembangkan kemampuan dalam menyampaikan ide dalam bentuk peta konsep. Sehingga peserta didik dapat meningkatkan kreativitas dan keaktifan dalam menyampaikan gagasan kepada teman-teman yang lainnya.

\section{METODE PENELITIAN}

Penelitian ini merupakan penelitian kuantitatif eksperimen. Penelitian ini menggunakan quasi eksperimental design jenis nonequivalent control group design. Berdasarkan jenis desain penelitian terdapat kelompok eksperimen dan kelompok kontrol, kedua kelompok lebih dulu diberikan pretest, kemudian diberikan perlakuan (post-test). Pada kelas eksperimen diberikan perlakuan model pembelajaran Student Facilitaotor And Explaning dengan butir soal dan pada kelompok kontrol hanya diberikan model pembelajaran konvensional. Penelitian ini dilaksanakan pada semester genap. Penelitian ini dilaksanakan pada peserta didik Kelas IV SDN 2 Golong yang terdiri dari 26 peserta didik dan peserta didik Kelas IV SDN 3 Peresak yang terdiri dari 25 peserta didik data yang dibutuhkan dalam penelitian ini adalah hasil belajar peserta didik. Metode pengumpulan data yang digunakan dalam penelitian ini adalah tes yang berjumlah 15 butir soal pilihan ganda dan lembar yang terdiri dar lembar observasi keterlaksanaan pembelajaran selama proses pembelajaran berlangsung. Teknik analisis data yang digunakan yaitu independent sample t-test dengan 2 uji prasyarat yakni uji normalitas menggunakan rumus kolmogrov-smirnov dan uji homogenitas menggunakan rumus levene test statistik berbantuan SPSS 21.0 for windows. Uji hipotesis menggunakan rumus independent sample t-test serta menggunakan effect size untuk melihat besar pengaruh model yang digunakan terhadap keterampilan proses IPA.

\section{HASIL DAN PEMBAHASAN}

Berdasarkan hasil observasi yang telah dilakukan melalui sintaks pembelajaran dalam penelitian ini menggunakan daftar cek (check list) $(\sqrt{ })$. Lembar observasi keterlaksanaan sintaks pembelajaran diisi oleh guru kelas IV untuk melihat keterlaksanaan pada kelas eksperimen. Keterlaksanaan sintaks pembelajaran pada kelas eksperimen menggunakan model pembelajaran SFE dapat dilihat pada Tabel 1.

Tabel 1. Persentase Keterlaksanaan Pembelajaran Kelas Eksperimen

\begin{tabular}{ccc}
\hline Pertemuan & Persentase (\%) & Kriteria \\
\hline I & $81,25 \%$ & Baik \\
II & $93,75 \%$ & Sangat Baik \\
\hline
\end{tabular}

Berdasarkan Tabel 1 di atas, dapat dilihat bahwa keterlaksanaan pembelajaran pertemuan pertama diperoleh persentase sebesar 81,25 dalam kategori baik dan pertemuan kedua sebesar 93,75 dengan kategori sangat baik. 
Butir soal yang sudah divalidasi digunakan sebagai soal pre-test dan post-test pada materi bangun ruang untuk mengukur hasil belajar peserta didik. Nilai rata-rata pre-test keterampilan proses IPA kelas eksperimen sebesar 40,19 serta kontrol sebesar 42,40 sedangkan nilai rata-rata post-test kelas eksperimen sebesar 66,54 dan kelas kontrol sebesar 59,20. Data hasil belajar peserta didik pre-test dan post-test peserta didik kelas kontrol dan eksperimen pada Tabel 2.

Tabel 2. Rata-rata nilai pre-test-post-test

\begin{tabular}{cccccc}
\hline Kelompok & Jumlah Siswa (N) & Tes & Nilai Tertinggi & Nilai Terendah & Rata-Rata \\
\hline Eksperimen & 26 & Pretest & 60 & 20 & 40,19 \\
& & Posttest & 85 & 45 & 66,54 \\
Kontrol & \multirow{2}{*}{25} & Pretest & 65 & 20 & 42,40 \\
& & Posttest & 80 & 40 & 59,20 \\
\hline
\end{tabular}

Selanjutnya dilakukan uji normalitas dengan menggunakan uji kolmogorov-smirnov dengan program analisis statistik SPSS.21 for windows pada data keterampilan proses IPA peserta didik ketika melaksanakan pre-test dan post-test pada kelas eksperimen dan kelas kontrol. kolmogorov-smirnov disajikan pada Tabel 3

Tabel 3. Hasil Uji Normalitas Pre-test dan Post-test

\begin{tabular}{lcccccr}
\hline & \multicolumn{3}{c}{ Kolmogorov-Smirnov } & \multicolumn{3}{c}{ Shapiro-Wilk } \\
\cline { 2 - 8 } & Statistic & df & \multicolumn{1}{c}{ Sig. } & Statistic & df & \multicolumn{1}{c}{ Sig. } \\
\hline Pretest_Eksperimen & .107 & 25 & $.200^{*}$ & .965 & 25 & .519 \\
Pretest_Kontrol & .097 & 25 & $.200^{*}$ & .970 & 25 & .639 \\
Posttest_Eksperimen & .142 & 25 & $.200^{*}$ & .941 & 25 & .158 \\
Posttest_Kontrol & .122 & 25 & $.200^{*}$ & .959 & 25 & .392 \\
\hline
\end{tabular}

Berdasarkan Tabel 3 di atas, hasil perhitungan uji normalitas didapatkan bahwa nilai signifikansi data pretest kelas kontrol serta eksperimen 0.200 , sementara itu untuk posttest kelas kontrol dan eksperimen 0.200. jika dibandingkan dengan nilai signifikan 0.05 semua data tersebut lebih besar dari nilai signifikansi sehingga dapat disimpulkan bahwa data pretest dan posttest kelas eksperimen maupun kontrol berdistribusi normal.

Tabel 4. Hasil Uji Homogenitas Pretest dan Posttest

\begin{tabular}{lcccc}
\hline & Levene Statistic & df1 & df2 & Sig. \\
\hline Nilai_Pretest & .288 & 1 & 49 & .594 \\
Nilai_Posttest & .245 & 1 & 49 & .623 \\
\hline
\end{tabular}

Berdasarkan Tabel 4 di atas, hasil perhitungan uji homogenitas data didapatkan bahwa nilai signifikansi data pretest sebesar 0.594 , sementara itu untuk posttest sebesar 0.623 jika dibandingkan dengan nilai signifikan 0.05 kedua data tersebut lebih besar dari nilai signifikansi sehingga dapat disimpulkan bahwa data pretest dan posttest dalam penelitian ini memiliki varian yang homogen.

Uji hipotesis dilakukan setelah uji normalitas dan uji homogenitas terpenuhi dengan data berdistribusi normal dan memiliki varian yang homogen. Oleh karena itu hipotesis dapat dilakukan dengan menggunakan uji-t yang bertujuan untuk mengetahui apakah terdapat pengaruh model student facilitator and explaining ( $s f e$ ) terhadap keterampilan proses IPA kelas IV SDN Gugus 6 Kecamatan Narmada. Uji hipotesis data menggunakan rumus independent sample $t$ test dengan bantuan SPSS.21 for windows.

Berdasarkan Tabel 5, hasil perhitungan uji hipotesis menggunakan Independent Sample t test diproleh nilai sig. 2 tailed sebesar $0.035<0.05$, jadi dapat disimpulkan bahwa $\mathrm{H}_{0}$ ditolak dan $\mathrm{H}_{\mathrm{a}}$ diterima sehingga terdapat pengaruh model student facilitator and explaining (sfe) terhadap keterampilan proses IPA kelas IV SDN Gugus 6 Kecamatan Narmada tahun ajaran 2020/2021. 
Tabel 5. Hasil uji t sampel independen

\begin{tabular}{llrrr}
\hline & & \multicolumn{2}{c}{ t-test for Equality of Means } \\
\cline { 3 - 4 } & & $\mathrm{d}$ & $\mathrm{df}$ & Sig. (2-tailed) \\
\hline \multirow{3}{*}{ Nilai_Posttest } & Equal variances assumed & 2.173 & 49 & .035 \\
& Equal variances not & 2.177 & 48.897 & .034 \\
\hline & & & \\
\hline
\end{tabular}

Penelitian ini bertujuan untuk menguji ada atau tidak ada pengaruh model pembelajaran SFE terhadap keterampilan proses IPA peserta didik kelas IV SDN Gugus 6 Kecamatan Narmada tahun ajaran 2019/2020. Sebelum melakukan penelitian, terlebih dahulu diuji kelayakan butir soal pada ahli bertujuan untuk mengkoreksi kesesuaian kisi-kisi instrumen pada tiap butir soal serta kesesuaian kalimat pada soal agar peserta didik dapat memahami maksud dari kalimat pada soal. Selanjutnya dilakukan uji lapangan pada 25 peserta didik di SDN 1 Peresak untuk mengetahui instrumen tersebut layak digunakan atau tidak dalam penelitian. Uji yang digunakan untuk menganalisis uji validitas soal menggunakan rumus kolerasi product moment pearson.

Hasil penelitian yang telah dilakukan di SDN 2 Golong menunjukkan bahwa nilai ratarata nilai posttest peserta didik kelas eksperimen adalah sebesar 66,54 sedangkan rata-rata nilai posttest peserta didik kelas kontrol sebesar 59,20. Hasil Posttest kelas eksperimen lebih tinggi dibandingkan dengan kelas kontrol pada keterampilan proses. Data pretest dan posttest digunakan untuk mencari nilai nilai uji normalitas dan homogenitas. Setelah data kedua kelas dinyatakan berdistribusi normal dan memiliki varian homogen selanjutnya dilakukan uji $t$ menggunakan Independent Sample t test untuk melihat perbedaan antara kelas eksperimen dan kontrol setelah diberikan perlakuan.

Penelitian terkait model ini juga sejalan dengan penelitian yang sudah dilakukan oleh Rizeqi dkk (2019: 46) dengan hasil menunjukkan: 1) prestasi belajar matematika peserta didik yang diajar menggunakan model pembelajaran SFE yang nilainya lebih dari atau sama dengan 70 melampaui $37 \%, 2$ ) motivasi, keterampilan proses kemudian prestasi belajar matematika peserta didik lebih baik yang diajar menggunakan model pembelajaran SFE dari pada model pembelajaran konvensional, 3) ada perbedaan motivasi, keterampilan proses dan prestasi belajar matematika peserta didik yang diajar menggunakan model pembelajaran SFE daripada yang diajar menggunakan model pembelajaran konvensional, 4) model pembelajaran SFE lebih baik daripada model pembelajaran konvensional terhadap motivasi, keterampilan proses dan prestasi belajar matematika.

Penelitian serupa juga dilakukan oleh Rianti (2017) dengan hasil diperoleh rata-rata pretes kelas eksperimen 61,02 meningkat menjadi 76,28 pada nilai postes, sedangkan rata-rata pretes kelas kontrol 57,01 meningkat menjadi 64,07 pada nilai postes. Berdasarkan hasil penelitian dapat disimpulkan siswa pada kelas eksperimen yang menggunakan Model Student Facilitator and Explaining (SFE) memperoleh hasil yang lebih baik dari siswa pada kelas kontrol yang hanya menggunakan metode konvensional. Dengan demikian, terdapat pengaruh Model Student Facilitator and Explaining (SFE) terhadap kemampuan pemahaman konsep IPA siswa.

Hasil analisis data penelitian yang telah dilakukan melalui. Menurut Yunita (2017) menyatakan bahwa analisis data dan pembahasan penerapan model SFE pada materi sistem ekskresi di kelas XI MIA 4 berpengaruh signifikan, hal ini terlihat dari uji hipotesis yang menyatakan bahwa. Penerapan model SFE juga berpengaruh terhadap kemampuan penguasaan konsep peserta didik, nilai posttest peserta didik yang seluruhnya di atas KKM. Secara keseluruhan penerapan model SFE menghasil perbandingan antara pretest $(55,46)$ dan posttest $(78,93)$ yang ditunjukkan dengan nilai gain $(0,32)$. Analisis hasil uji t nilai probabilitas (signifikansi) $<0,05$ yang berarti Ho ditolak dan Ha diterima.

Mulai penggunaan pembelajaran diskusi keterampilan proses IPA yang telah dilakukan oleh. Menurut Kamalia (2010:28) menyatakan bahwa keterampilan berarti kemampuan 
menggunakan pola pikiran, nalar dan perbuatan secara efisien dan efektif untuk mencapai tujuan termasuk kreativitas, sehingga proses dapat didefinisikan sebagai perangkat keterampilan kompleks yang digunakan ilmuan dalam melalukan penelitian ilmiah. Proses juga merupakan konsep besar yang dapat diuraikan menjadi komponen - komponen yang harus dikuasai seseorang bila melakukan penelitian.

Sedangkan menurut Marini (2012) keterampilan proses adalah pembelajaran yang dirancang sedemikian rupa, sehingga siswa dapat menentukan fakta-fakta, menentukan faktafakta, membangun konsep-konsep dan teori-teori dengan keterampilan proses intelektual dan sikap ilmiah seperti yang dikerjakan pada ilmuan, tetapi pendekatan keterampilan proses tidak bermaksud menjadi setiap menjadi ilmu. Keterampilan berarti kemampuan menggunakan pikiran, nalar dan perbuatan secara efisien dan efektif untuk mencapai suatu hasil tertentu, termasuk kreativitas.

Hasil Penelitian ini dapat disimpulkan bahwa penggunaan model SFE dengan cara diskusi sangat membantu dan meningkatkan hasil belajar yang lebih tinggi yang maksimal namun yang telah dilakukan hasil yang diperoleh yaitu membuktikan bahwa ada pengaruh model pembelajaran SFE terhadap keterampilan proses IPA kelas IV SDN Gugus 6 Kecamatan Narmada.

\section{KESIMPULAN}

Berdasarkan hasil penelitian dan pembahasan pada bab sebelumnya bahwa hasil uji hipotesis menggunakan uji independent sample $t$ test, maka dapat disimpulkan bahwa terdapat pengaruh model pembelajaran student facilitator and explaining terhadap keterampilan proses IPA siswa kelas IV. Sesuai dengan hasil penelitian serta data yang telah dianalisis maka peneliti dapat menyimpulkan bahwa model student facilitator and explaining terhadap keterampilan proses IPA siswa di kelas eksperimen.

\section{DAFTAR PUSTAKA}

Kamalia, D. P. (2010). Pendekatan Keterampilan Proses Pada Pembelajaran IPA Kelas V. 3 (1) 57 64.

Kurniasih I \& Sani B. (2015). Ragam Pengembangan Model Pembelajaran Untuk Meningkatlkan Profesinalitas Guru. 7(2) 146-151.

Lestari, I. (2014). Pengaruh Model Student Facilitator and Explaning Terhadap Hasil Belajar IPA Kelas V. Singaraja: Indonesia

Lestari,I. (2017). Pengaruh Model Student Facilitator and Explaning Terhadap Hasil Belajar IPA Kelas V. 3(2) 1-4.

Nuryanto. (2018) Penggunaan model Student facilitator And Explaining pada pembelajaran IPA. $1(2) 1-2$.

Nyunita. (2017). Pengeruh Penerapan Model Pembelajaran Kooperatif Tipe Student Facilitator And Expalining (SFE) Terhadap Penguasaan Konsep Peserta Didik kelas XI Negeri 1 Talang Materi Sistem Eskresi. Palembang: Universitas Sriwijaya.

Marini. (2018). Penggunaan Pendekatan keterampilan Proses untuk Meningkatkan Hasil Belajar Siswa Kelas IV SDN 024 Salukaili. Jurnal ilmiah Sekolah Dasar. 4(2) 108-10.

Mustikasari, I., Supand., Damayani. A.T. (2019). Pengaruh Model Student Facilitator And Expalining (SFAE) Terhadap Kemampuan Berpikir Kritis. Jurnal Ilmiah Sekolah Dasar. 3(3) 303-30.

Prasetyo, E. (2010). Pengaruh Model Student Facilitator and Explaining Terhadap Aktivitas dan Hasil Belajar Siswa Materi Inversitas SMA 1 Bojo. Semarang: Universitas Negeri Semarang.

Rezki, M., Farman.A.S.,Fuadiyah.S,Lufri. (2018). Pengaruh Model Student Facilitator And Expalining (SFAE) Terhadap Kompetensi Belajar Peserta Didik Materi Pemanasan Global di 4 Kota XI Tarusan. Jurnal IImiah Sekolah Dasar. 4(6).

Rizqi, N., Isnaini., \& Sina, I. (2019). Keefektifan Model Pembelajaran SFE terhadap Motivasi, Keterampilan Proses dan Prestasi Belajar Matematika. Jurnal Pendidikan Matematika Pancasakti. 3(1) 24-29. doi: https://doi.org/10.24905/jpmp.v3i1.1299 
Rianti, L., Nulhakim, L. (2017). Pengaruh Model Student Facilitator And Explaining (SFAE) Terhadap Pemahaman Konsep Siswa Kelas IV Pada Mata Pelajaran IPA. JPSD. 3(1) 64-73. doi: http://dx.doi.org/10.30870/ipsd.v3i1.1329

Sugiyono. (2014). Metode Penelitian Pendidikan Pendekatan Kualitatif Kuantitatif. Bandung: Alfabeta

Trianto. (2014). Model Pembelajaran Terpadu. Jakarta: PT Bumi Aksara.

Trianto. (2007). Model-Model Pembelajaran Inovatif Berorientasi Konstruktivistis. Surabaya: Bumi Aksara.

Wiratningsih. (2014). Pengaruh Student Facilitator And Explaining ,Berbantuan Peta Konsep Terhadap Hasil PKn Kelas V SD Gugus 1 gusti Ngurah Rai. Jurnal Mimbar PGSD. Universitas pendidikan Ganesha. 